\title{
Activity of Benomyl for Control of Postbloom Fruit Drop of Citrus Caused by Colletotrichum acutatum
}

\author{
N. A. R. Peres, Ph.D. candidate, and N. L. Souza, Professor, Universidade Estadual Paulista, FCA, Botucatu, SP, \\ Brazil; and S. E. Zitko, former Senior Biologist, and L. W. Timmer, Professor, University of Florida, Citrus Re- \\ search and Education Center, Lake Alfred 33850
}

\begin{abstract}
Peres, N. A. R., Souza, N. L., Zitko, S. E., and Timmer, L. W. 2002. Activity of benomyl for control of postbloom fruit drop of citrus caused by Colletotrichum acutatum. Plant Dis. 86:620624.

Postbloom fruit drop (PFD) of citrus caused by Colletotrichum acutatum produces orangebrown lesions on petals and induces the abscission of young fruitlets and the retention of the calyces. Despite the fact that $C$. acutatum is not highly sensitive to benomyl in culture, this fungicide provides good control of the disease under field conditions. This study was undertaken to determine the effect of benomyl on various stages of disease development to understand the basis for its effectiveness in the field. We found that benomyl at $1.0 \mu \mathrm{g} / \mathrm{ml}$ reduced colony area of $C$. acutatum by about $75 \%$ and completely inhibited growth of C. gloeosporioides. Benomyl did not prevent conidial germination even at $100 \mu \mathrm{g} / \mathrm{ml}$, but reduced germ tube elongation at 10 and $100 \mu \mathrm{g} / \mathrm{ml}$. When benomyl was applied to flower clusters on screenhouse-grown plants before inoculation, disease severity was greatly reduced. Applications at 24 and $48 \mathrm{~h}$, but not at $72 \mathrm{~h}$, after inoculation reduced PFD severity. Application of benomyl to symptomatic petals not bearing conidia did not prevent or reduce production of inoculum. Application to petals bearing conidia reduced viability of these fungal propagules by only about $50 \%$. The viability of appressoria on mature leaves was not affected by benomyl application. Even when appressoria on mature leaves were stimulated to germinate by treatment with flower extracts, subsequent application of benomyl did not reduce propagule numbers below original levels. Benomyl appears to act by preventing infection and early development of the fungus in petals. However, once symptoms have developed, this fungicide has only minimal effects on further disease development and spread.
\end{abstract}

Postbloom fruit drop (PFD), caused by Colletotrichum acutatum J. H. Simmonds, produces orange-brown lesions on petals of citrus flowers and induces the abscission of fruitlets $(20,21)$. Calyces from these flowers, commonly called buttons, persist for the life of the twig and are diagnostic for the disease. Conidia are produced in acervuli on infected petals and are dispersed by wind-blown rain during the bloom period (20,21). Conidia deposited on leaves and other vegetative tissues germinate and form thick-walled, pigmented appressoria which serve as survival structures between flowering periods. Unlike appressoria of $C$.

Corresponding author: N. A. R. Peres

E-mail: narperes@webcable.com.br

This research was supported in part by DuPont Agricultural Products and the Florida Citrus Production Research Advisory Council, Project 99136P; and by the Florida Agricultural Experiment Station, and was approved for publication as Journal Series No. R-08206.

Current address of third author: BASF Corporation, P.O. Box 400, Princeton, NJ 08543-0400.

Accepted for publication 29 January 2002

Publication no. D-2002-0322-02R

(C) 2002 The American Phytopathological Society gloeosporioides (Penz.) Penz. \& Sacc. in Penz. that germinate and infect senescent tissues $(21,22)$, appressoria of $C$. acutatum germinate and produce a few conidia on the leaf surface (28). These conidia are then splashed onto the first flowers of the new season to continue the cycle.

The PFD pathogen is widely distributed in the Americas (20). Serious losses occur sporadically in Florida and Brazil when rains occur during the bloom period (15). The disease is endemic in the humid tropics of the Americas, where trees may flower any time of year, and has an important effect on yields annually in Central America, eastern Mexico, and the Caribbean.

PFD was reported first in Belize in 1979 and early studies on control indicated that benomyl and captafol were the most effective fungicides for control of the disease $(7,8)$. In Florida, benomyl has been highly effective for control of PFD in the field $(15,23,25)$. Benomyl applications have reduced flower infection, the number of buttons, and increased yields up to $600 \%$ compared with the nontreated control (25). Nevertheless, C. acutatum isolates from citrus are not highly sensitive to benomyl in culture $(11,16)$. Colony diameter of $C$. acutatum isolates from citrus is generally reduced to about $50 \%$ of the control at 1 $\mu \mathrm{g} / \mathrm{ml}$, but higher concentrations do not reduce growth much further. On the other hand, growth of $C$. gloeosporioides is completely inhibited by benomyl at 1 $\mu \mathrm{g} / \mathrm{ml}$.

Isolates of $C$. acutatum from other crops are not very sensitive to benomyl. Growth of isolates of $C$. acutatum from deciduous fruits was reduced by 20 to $50 \%$ with benomyl at $2 \mu \mathrm{g} / \mathrm{ml}$, whereas $C$. gloeosporioides isolates were completely inhibited (4). Peach and almond isolates of $C$. acutatum in California were insensitive to benomyl in a fungicide disc assay (1). In a recent review, Freeman et al. (9) considered all C. acutatum isolates to be insensitive to benomyl.

Due to the lack of sensitivity of $C$. acutatum to benomyl in culture, this fungicide has not been widely tested in the field against diseases caused by this pathogen. When tested against ripe rot of blueberry, benomyl significantly reduced disease severity on one of two cultivars tested (6). Benomyl is considered ineffective for control of anthracnose on leatherleaf fern caused by C. acutatum (17) and for control of anthracnose fruit rot on strawberries (12).

C. acutatum is not highly sensitive to benomyl in culture and benomyl performs poorly for control of diseases caused by $C$. acutatum on other crops; therefore, it is of interest to determine why benomyl is so effective for control of PFD on citrus. This study was undertaken to determine the effect of benomyl on the various stages of disease development to ascertain the basis for its effectiveness.

\section{MATERIALS AND METHODS}

The isolates of $C$. acutatum used in this study were recovered from infected petals of sweet orange flowers in various areas of Florida. C. gloeosporioides isolates were recovered from dead leaves and twigs. All C. acutatum isolates were maintained as dried cultures on sterile filter paper in sealed plastic containers with desiccant at $-20^{\circ} \mathrm{C}$. Cultures were grown on potato dextrose agar (PDA) at $27^{\circ} \mathrm{C}$ for production of conidia and mycelial plugs.

Sensitivity to benomyl in vitro. Cultures of C. acutatum (isolates CS-1, Maran, and Mayo) and C. gloeosporioides (isolates GND-1, TH-4, and Dil-Ark-1) were grown on PDA for 1 week and 0.5$\mathrm{cm}$-diameter mycelial plugs were cut from 
the margins of the colony. These plugs were transferred to three petri dishes each of PDA containing benomyl (as Benlate 50WP, DuPont Crop Protection, Wilmington, DE) at $0,0.1,1.0,10,100$, and 1,000 $\mu \mathrm{g} / \mathrm{ml}$. Cultures were incubated for 1 week at $24^{\circ} \mathrm{C}$ with a photoperiod of $12 \mathrm{~h}$ light and $12 \mathrm{~h}$ dark. Colony radius was measured and the area calculated and expressed as a percentage of the control.

The effect of benomyl concentrations on conidial germination and germ tube growth was determined for isolates CS-1, Maran, and Mayo. Conidia of each isolate were harvested from cultures on PDA in sterile distilled water and added to potato dextrose broth (PDB) at a final concentration of $10^{4}$ conidia $/ \mathrm{ml}$. Three replicate petri dishes with $20 \mathrm{ml}$ of PDB each were used for each isolate-benomyl concentration combination. Benomyl was added to dishes to make a final concentration of $0,0.1,1.0$, 10 , and $100 \mu \mathrm{g} / \mathrm{ml}$ immediately after conidia were added. Conidia were incubated at $24^{\circ} \mathrm{C}$ for $24 \mathrm{~h}$ and the percentage of conidia germinated determined microscopically. The length of the germ tube on the longest axis was measured using an eyepiece micrometer for 10 germinated conidia per petri dish.

The effect of the fungicide on mycelial growth from conidia was assessed in another experiment. Conidia were allowed to germinate overnight and form a short germ tube before benomyl was added. The germ tube length was determined $12 \mathrm{~h}$ later.

Pre- and post-infection activity of benomyl. The efficacy of pre- and postinoculation applications of benomyl was evaluated on 4- to 8-year-old potted citrus trees in four separate experiments in the screenhouse. Experiments 1 and 2 were conducted on Valencia sweet orange (Citrus sinensis (L.) Osb.), experiment 3 on Orlando tangelo $(C$. paradisi Macf. $\times C$. reticulata Blanco), and experiment 4 on tangerines $(C$. reticulata). The treatments used were benomyl as Benlate 50WP (1.2 $\mathrm{g}$ a.i./liter) applied $24 \mathrm{~h}$ prior to inoculation and at 24, 48, and $72 \mathrm{~h}$ after inoculation. For each treatment, six clusters with a few open flowers, some buds, and some pinhead flowers were selected. Conidia of isolate SGR-FTP-1 were washed from the surface of cultures on PDA and diluted in distilled water to a concentration of $10^{5}$ conidia $/ \mathrm{ml}$. Flower clusters were spray inoculated with conidia, covered with plastic bags, and maintained at ambient temperature $\left(18\right.$ to $\left.25^{\circ} \mathrm{C}\right)$ for $16 \mathrm{~h}$. The plastic bags were removed and the plants maintained in the screenhouse. The number of symptomatic and total flowers was counted after 1 week and the data expressed as the percentage of infected flowers. About 1 month after inoculation, the number of persistent calyces was counted for each cluster.

Conidial production and viability. Sweet orange flowers on plants in the screenhouse were inoculated as in the previous experiment. Petals affected by PFD were collected to measure the effect of benomyl on conidial production in two experiments. In experiment 1 , the infected petals collected had not yet formed conidia. In experiment 2 , petals with conidia were collected and vortexed in distilled water to remove conidia. Petals were selected for uniformity with about 50 to $60 \%$ of the surface area showing necrosis in experiment 1 and about 75 to $80 \%$ in experiment 2. Petals then were placed in petri dishes with moist filter paper. In all, 5 petals per treatment were used in experiment 1 and 10 in experiment 2. Petals were sprayed with benomyl at $1.2 \mathrm{~g}$ a.i./liter or left unsprayed. Treated and untreated petals were incubated for $16 \mathrm{~h}$ on the laboratory bench at room temperature (22 to $25^{\circ} \mathrm{C}$ ). Each petal was vortexed in $10 \mathrm{ml}$ of distilled water and the resultant conidial suspension diluted and counted on a hemacytometer. Data were expressed as the mean number of conidia per petal.

Similarly, symptomatic petals with abundant conidia were collected from inoculated sweet orange trees to assess the effect of benomyl on conidial viability. Three experiments were conducted using 10 petals for each treatment. Petals were placed in petri dishes with moist filter paper and treated with benomyl as above or left unsprayed. Petals were incubated for $16 \mathrm{~h}$ and conidial numbers per petal counted as above, except sterile distilled water was used to collect conidia. Conidia were diluted to 100 and to $1,000 / \mathrm{ml}$, and $0.1 \mathrm{ml}$ of each suspension was spread onto each of three petri dishes of PDA per flower petal. The plates were incubated for 3 days at $27^{\circ} \mathrm{C}$ and the number of colonies counted. Data were expressed as the number of viable conidia per petal.

Effect of benomyl on pathogen survival. The effects of benomyl on appressoria on the leaf surface and on propagules produced after appressoria were stimulated to germinate were evaluated. Appressoria were stimulated to germinate by application of flower extracts, after which the benomyl was applied in an attempt to eliminate residual inoculum on the leaves. The flower extract was prepared by macerating flower petals in four parts water to one part petal tissue. Conidia of the Maran, Mayo, and CS-1 isolates of C. acutatum were produced on PDA and washed from the surface of the culture in water, after which the concentration was adjusted to $10^{5} / \mathrm{ml}$ using a hemacytometer. Ten 1-yearold sweet orange seedlings (two plants per treatment) growing in potting mix in 2.7liter pots were used for each experiment. The experiment was conducted four times. All plants were sprayed to run-off with the conidial suspension. Plants were placed in a dew chamber at $25^{\circ} \mathrm{C}$ for $48 \mathrm{~h}$ to allow conidia to germinate and form appressoria. Plants then were transferred to a greenhouse and leaves maintained dry for about 30 days to allow ungerminated conidia to die, leaving only appressoria (28). Two plants each were subjected to the following treatments: (i) sprayed with water followed by benomyl at $1.2 \mathrm{~g}$ a.i./liter 2 days later, (ii) sprayed with water followed by water 2 days later, (iii) sprayed with flower extract followed by benomyl 2 days later, (iv) sprayed with flower extract followed by water 2 days later, and (v) untreated control. All plants then were placed in the greenhouse under dry conditions for 3 days. Ten leaves were collected from each treatment before the first application and 3 days after the last application and propagules were removed using the procedure of Agostini and Timmer (3). Briefly, 10 to 15 leaf discs were cut from each leaf, and leaf discs were placed in a test tube with $10 \mathrm{ml}$ of water. Tubes were vortexed for $10 \mathrm{~min}$ at high speed to remove propagules from the leaf surface. Aliquots of $0.1 \mathrm{ml}$ from each tube were plated on five petri dishes of the selective medium for Colletotrichum spp. (2). Propagules were incubated for 4 days at $18^{\circ} \mathrm{C}$ and for 1 day at $27^{\circ} \mathrm{C}$. The number of colonies of C. acutatum was counted and expressed as propagules per unit of leaf surface area.

\section{RESULTS}

Sensitivity to benomyl in vitro. Isolates of $C$. acutatum from our collection were not highly sensitive to benomyl (Table 1). This fungicide reduced colony area by 60 to $70 \%$ of the control at $0.1 \mu \mathrm{g} / \mathrm{ml}$ and to about $25 \%$ of the control at 1.0 $\mu \mathrm{g} / \mathrm{ml}$, but increases in the fungicide concentration did not reduce growth much

Table 1. Effect of benomyl at different concentrations on the growth of isolates of Colletotrichum acutatum and C. gloeosporioides on potato dextrose agar

\begin{tabular}{lccccc}
\hline & \multicolumn{5}{c}{ Colony area as \% of control per benomyl concentration $(\boldsymbol{\mu g} / \mathbf{m l})^{\mathbf{z}}$} \\
\cline { 2 - 6 } Species, isolate & $\mathbf{0 . 1}$ & $\mathbf{1 . 0}$ & $\mathbf{1 0}$ & $\mathbf{1 0 0}$ & $\mathbf{1 , 0 0 0}$ \\
\hline C. acutatum & & & & & \\
CS-1 & $70.4 \pm 1.3$ & $27.5 \pm 0.4$ & $24.0 \pm 1.8$ & $22.6 \pm 0.9$ & $10.4 \pm 0.4$ \\
Mayo & $62.7 \pm 2.9$ & $24.6 \pm 0.3$ & $18.5 \pm 0.3$ & $19.9 \pm 0.6$ & $12.4 \pm 0.6$ \\
Maran & $60.5 \pm 3.9$ & $26.1 \pm 0.6$ & $21.9 \pm 1.6$ & $21.9 \pm 1.0$ & $11.0 \pm 0.4$ \\
C. gloeosporioides & & & & & \\
GND-1 & $12.7 \pm 1.8$ & 0.0 & 0.0 & 0.0 & 0.0 \\
TH-4 & $16.5 \pm 3.6$ & 0.0 & 0.0 & 0.0 & 0.0 \\
Di1-Ark-1 & $32.0 \pm 0.7$ & 0.0 & 0.0 & 0.0 & 0.0 \\
\hline
\end{tabular}

${ }^{\mathrm{z}}$ Mean \pm SE of three replicate plates. 
further. In contrast, the colony area of $C$. gloeosporioides was 12 to $32 \%$ of the control at $0.1 \mu \mathrm{g} / \mathrm{ml}$, and no growth occurred at higher concentrations.

The addition of benomyl to conidia of C. acutatum did not prevent spore germination of $\mathrm{C}$. acutatum even at the highest concentration tested $(100 \mu \mathrm{g} / \mathrm{ml})$. Benomyl at $0.1 \mu \mathrm{g} / \mathrm{ml}$ did not reduce the hyphal growth of any of the isolates, even when added before germination (Table 2). Benomyl at $1.0 \mu \mathrm{g} / \mathrm{ml}$ reduced growth of the Maran isolate by $34 \%$, but did not reduce growth of the CS-1 or Mayo isolates. At 10 and $100 \mu \mathrm{g} / \mathrm{ml}$, hyphal growth of all isolates was reduced by about 70 to $80 \%$.

Results were similar when benomyl was added to conidia which had already germinated (Table 2). Concentrations of 0.1 and $1.0 \mu \mathrm{g} / \mathrm{ml}$ only slightly reduced growth, but 10 and $100 \mu \mathrm{g} / \mathrm{ml}$ reduced growth by 55 to $80 \%$.

Pre- and post-infection activity of benomyl. Benomyl applied to flowers 24 $\mathrm{h}$ prior to inoculation reduced the number of infected flowers by 70 to $100 \%$ and the number of persistent calyces formed on the inflorescences by 75 to $80 \%$ (Table 3). Applications at 24 and $48 \mathrm{~h}$ after the inoculation reduced the flower infection and button formation by 50 to $75 \%$. However, applications $72 \mathrm{~h}$ after inoculation only reduced symptom development in one experiment where disease was not severe.

Conidial production and viability. Applications of benomyl to infected, symptomatic petals without conidia failed to prevent the production of conidia (Table 4). Conidial numbers were the same or higher on benomyl-treated petals as on nontreated controls. Application of benomyl to conidia already present on petals appeared to reduce their viability by about $40 \%$.

Effect of benomyl on survival. Application of benomyl to sweet orange leaves with appressoria present did not reduce the number of propagules recovered from those leaves compared with the water treatment or the nontreated control (Table 5). The number of propagules recovered was not significantly different from the number recovered from the same plants prior to treatment. Application of the flower extract tripled the number of propagules recovered from leaves of the same plants prior to treatment and increased the number of propagules as much or more compared with nontreated and water-sprayed controls. However, application of benomyl following the flower extract treatment failed to eliminate propagules. The flower extract followed by benomyl treatment reduced propagules to the same level observed prior to treatment, and numbers were similar to those in the controls.

\section{DISCUSSION}

The ability of benomyl to control PFD caused by $C$. acutatum on citrus appears to be unique. Our results show that $C$. $a c u$ tatum isolates from citrus are not highly sensitive to benomyl in vitro, confirming results of other studies on citrus $(11,16)$ and other crops $(1,4,9)$. Nevertheless, in early studies in Belize $(7,8)$ and subsequent work in Mexico (14) and Florida $(15,24,25)$, benomyl has proven as effective or more effective than other fungicides in controlling PFD.

Although C. acutatum is not highly sensitive to benomyl, low concentrations inhibit substantially growth in vitro. Colony diameter of $C$. acutatum is usually reduced by about $50 \%$ at $1.0 \mu \mathrm{g} / \mathrm{ml}$ compared with the unamended control $(11,16)$. However, when growth was measured as colony area, we found that growth is reduced by $50 \%$ by $0.1 \mu \mathrm{g} / \mathrm{ml}$. If growth were measured as mycelial dry weight, the concentration to achieve to $50 \%$ inhibition might be even lower. Germination of conidia even in the presence of high concentrations of benomyl was virtually $100 \%$. The effect of benomyl on the growth of germ tubes was similar to the effect on growth of mycelium in culture, except that the effect of low concentrations was not apparent. Thus, despite the fact that benomyl does not kill or provide $100 \%$ inhibition, even at high concentrations, it substantially reduced the growth of $C$. acutatum in petals of citrus.

Benomyl has excellent postinfection activity against many diseases. This fungicide provides good control of apple scab and other diseases of deciduous fruit crops $(13,18,19)$, even when applied as late as 3 to 5 days after infection. Bushong and Timmer (5) found that benomyl provided excellent control of citrus scab when applied up to 3 days after inoculation. On citrus flowers inoculated with $C$. acutatum, benomyl was effective when applied within $48 \mathrm{~h}$ after inoculation. However,

Table 2. Effect of benomyl on germ tube growth of conidia of Colletotrichum acutatum

\begin{tabular}{|c|c|c|c|c|c|c|}
\hline \multirow[b]{2}{*}{ Isolate } & \multirow[b]{2}{*}{ Time $(h)^{\mathrm{z}}$} & \multicolumn{5}{|c|}{ Length $(\mu \mathrm{m})$ per benomyl concentration $(\mu \mathrm{g} / \mathrm{ml})^{y}$} \\
\hline & & 0.0 & 0.1 & 1.0 & 10 & 100 \\
\hline CS-1 & 0 & $1,360 \pm 42$ & $1,450 \pm 35$ & $1,520 \pm 90$ & $299 \pm 15$ & $328 \pm 28$ \\
\hline Maran & 0 & $1,257 \pm 26$ & $1,265 \pm 37$ & $833 \pm 39$ & $334 \pm 28$ & $327 \pm 10$ \\
\hline Mayo & 0 & $1,621 \pm 31$ & $1,770 \pm 55$ & $1,687 \pm 24$ & $478 \pm 70$ & $425 \pm 23$ \\
\hline CS-1 & 12 & $1,367 \pm 18$ & $1,033 \pm 41$ & $1,121 \pm 30$ & $431 \pm 11$ & $252 \pm 12$ \\
\hline Maran & 12 & $1,302 \pm 41$ & $1,070 \pm 8$ & $903 \pm 9$ & $491 \pm 10$ & $281 \pm 2$ \\
\hline Mayo & 12 & $1,356 \pm 52$ & $1,288 \pm 21$ & $1,182 \pm 46$ & $604 \pm 25$ & $304 \pm 19$ \\
\hline
\end{tabular}

${ }^{\mathrm{y}}$ Mean \pm SE of the three replicates.

${ }^{\mathrm{z}}$ Benomyl applied before (0) or $12 \mathrm{~h}$ after conidial germination.

Table 3. Effect of pre- and postinoculation applications of benomyl on the development of symptoms of postbloom fruit drop caused by Colletotrichum acutatum $^{\mathrm{w}}$

\begin{tabular}{|c|c|c|c|c|c|c|c|c|c|c|}
\hline \multirow[b]{3}{*}{ Time $(h)^{x}$} & \multicolumn{10}{|c|}{ Experiment number } \\
\hline & \multicolumn{2}{|c|}{1} & \multicolumn{2}{|c|}{2} & \multicolumn{2}{|c|}{3} & \multicolumn{2}{|c|}{4} & \multicolumn{2}{|c|}{ Mean } \\
\hline & $\begin{array}{c}\text { Flowers } \\
(\%)^{\mathrm{y}}\end{array}$ & $\begin{array}{c}\text { Persistent } \\
\text { calyces }^{z}\end{array}$ & $\begin{array}{l}\text { Flowers } \\
(\%)\end{array}$ & $\begin{array}{c}\text { Persistent } \\
\text { calyces }\end{array}$ & $\begin{array}{c}\text { Flowers } \\
(\%)\end{array}$ & $\begin{array}{c}\text { Persistent } \\
\text { calyces }\end{array}$ & $\begin{array}{c}\text { Flowers } \\
(\%)\end{array}$ & $\begin{array}{l}\text { Persistent } \\
\text { calyces }\end{array}$ & $\begin{array}{c}\text { Flowers } \\
(\%)\end{array}$ & $\begin{array}{l}\text { Persistent } \\
\text { calyces }\end{array}$ \\
\hline Control & $5 \mathrm{a}$ & $7 \mathrm{a}$ & $16 \mathrm{a}$ & $12 \mathrm{a}$ & $42 \mathrm{a}$ & $15 \mathrm{a}$ & $57 \mathrm{a}$ & $3 a$ & $30 \mathrm{a}$ & $9 \mathrm{a}$ \\
\hline-24 & $0 \mathrm{~b}$ & $2 \mathrm{~b}$ & $0 \mathrm{~b}$ & $3 \mathrm{ab}$ & $1 \mathrm{~b}$ & $2 \mathrm{~cd}$ & $17 \mathrm{~b}$ & $2 a b$ & $6 \mathrm{c}$ & $2 b$ \\
\hline+24 & $0 \mathrm{~b}$ & $3 a b$ & $10 \mathrm{ab}$ & $4 a b$ & $4 \mathrm{~b}$ & $1 \mathrm{~d}$ & $12 \mathrm{~b}$ & $2 a b$ & $8 \mathrm{bc}$ & $3 \mathrm{~b}$ \\
\hline+48 & $0 \mathrm{~b}$ & $2 b$ & $14 \mathrm{a}$ & $12 \mathrm{a}$ & $12 \mathrm{~b}$ & $1 \mathrm{~d}$ & $18 \mathrm{~b}$ & $1 \mathrm{~b}$ & $13 \mathrm{bc}$ & $4 \mathrm{ab}$ \\
\hline+72 & $0 \mathrm{~b}$ & $2 b$ & $10 \mathrm{ab}$ & $1 \mathrm{~b}$ & $35 a$ & $8 \mathrm{bc}$ & $37 \mathrm{ab}$ & $3 a$ & $22 \mathrm{ab}$ & $4 \mathrm{ab}$ \\
\hline
\end{tabular}

${ }^{\mathrm{w}}$ Mean separation by the Waller-Duncan $k$-ratio $t$ test, $P \leq 0.05$.

$\mathrm{x}$ Application time after inoculation (h).

y Average percentage of symptomatic flowers affected per cluster.

${ }^{\mathrm{z}}$ Number of persistent calyces remaining per cluster. 
benomyl is able to prevent symptom development and, presumably, sporulation if applied soon after infection.

With many diseases, benomyl also is capable of preventing inoculum production on symptomatic tissue and eliminating inoculum. Benomyl prevents ascospore production by the apple scab fungus $(10,18,19)$. This fungicide reduced pycnidial production on citrus twigs affected by melanose (27) and prevented development of pseudothecia and ascospores of $M y$ cosphaerella citri, the causal agent of citrus greasy spot (26). With citrus scab, benomyl can eradicate fungal tissue in pustules and reduce sporulation on the surface (24). With PFD, benomyl did not reduce conidial production on infected symptomatic tissue and only marginally reduced the viability of existing inoculum. Thus, once the infection is well established in the petal, benomyl application probably does little to slow the epidemic.

Benomyl applications made to vegetative tissue prior to flowering could potentially reduce residual appressoria and postpone the onset of the epidemic. However, we found no indication that benomyl affected viability directly. Even when flower extracts were applied to stimulate germination of appressoria, benomyl applications did not eliminate viable propagules from the leaf surface. These results were consistent with previous work, indicating that viability of appressoria of $C$. acutatum on fruit is not affected by postharvest applica- tion of the related fungicide, thiabendazole (22). In contrast, postharvest application of benzimidazole fungicides to fruit bearing appressoria of C. gloeosporioides strongly inhibits development of the fungus and prevents postharvest anthracnose $(21,22)$.

The activity of benomyl in controlling PFD appears to lie in its ability to prevent infection, reduce mycelial development, and prevent sporulation on treated petals. Concentrations of fungicide as applied by sprayers in the field range from 250 to $1,000 \mathrm{~g} /$ liter, which should be more than adequate to prevent growth of $C$. acutatum. Once symptoms have developed, benomyl appears to have little effect on epidemic development. C. acutatum is not highly sensitive to benomyl in culture; therefore, few field tests have been conducted to evaluate its efficacy on diseases of other crops caused by $C$. acutatum. It could prove more effective than results in culture might indicate. C. acutatum is not highly sensitive to benomyl and apparently does not readily develop resistance to this fungicide (15; unpublished data). C. gloeosporioides, which is highly sensitive, can develop resistance to benomyl quickly. Germination of conidia of $C$. acutatum is not affected by benomyl; therefore, there may be no selection for mutations that occur for resistance.

\section{ACKNOWLEDGMENTS}

We thank Fundação de Amparo a Pesquisa do Estado de São Paulo for support of N. A. R. Peres during a portion of this research project.

Table 4. Effect of benomyl application to detached, infected sweet orange petals on production of conidia of Colletotrichum acutatum symptomatic petals, and on the viability of conidia from symptomatic petals already bearing spores ${ }^{\mathrm{x}}$

\begin{tabular}{lccccccrrr}
\hline & \multicolumn{3}{c}{ Conidia/petal $\left(\times \mathbf{1 0}^{\mathbf{6}}\right)$ per experiment $\mathbf{y}^{\mathbf{y}}$} & & \multicolumn{3}{c}{ Viable conidia/petal $\left(\times \mathbf{1 0}^{\mathbf{6}}\right)$ per experiment } \\
\cline { 2 - 4 } Treatment & $\mathbf{1}$ & $\mathbf{2}$ & Mean & & $\mathbf{1}$ & $\mathbf{2}$ & $\mathbf{3}$ & Mean \\
\hline Control & $5.30 \mathrm{a}$ & $5.43 \mathrm{~b}$ & $6.68 \mathrm{a}$ & & $23.2 \mathrm{a}$ & $5.3 \mathrm{a}$ & $10.6 \mathrm{a}$ & $13.0 \mathrm{a}$ \\
Benomyl & $4.06 \mathrm{a}$ & $7.99 \mathrm{a}$ & $5.39 \mathrm{a}$ & & $14.6 \mathrm{a}$ & $3.7 \mathrm{~b}$ & $5.5 \mathrm{~b}$ & $7.9 \mathrm{~b}$ \\
\hline
\end{tabular}

${ }^{\mathrm{x}}$ Mean separation by the Waller-Duncan $k$-ratio $t$ test, $P \leq 0.05$.

${ }^{y}$ Benomyl at $2.4 \mu \mathrm{g}$ a.i./ml was applied to symptomatic petals without conidia; treated and nontreated petals were incubated for $16 \mathrm{~h}$ and the number of conidia produced counted.

${ }^{\mathrm{z}}$ Benomyl at $1.2 \mu \mathrm{g}$ a.i./ml was applied to symptomatic petals with abundant conidia; viable conidia per petal was determined by dilution plating after $16 \mathrm{~h}$ of incubation.

LITERATURE CITED

1. Adaskaveg, J. E., and Hartin, R. J. 1997. Characterization of Colletotrichum acutatum isolates causing anthracnose of almond and peach in California. Phytopathology 87:97987.

2. Agostini, J. P., and Timmer, L. W. 1992. Selective isolation procedures for differentiation of two strains of Colletotrichum gloeosporioides from citrus. Plant Dis. 76:11761178.

3. Agostini, J. P., and Timmer, L. W. 1994. Population dynamics and survival of strains of Colletotrichum gloeosporioides on citrus in Florida. Phytopathology 84:420-425.

4. Bernstein, B., Zehr, E. I., Dean, R. A., and Shabi, E. 1995. Characteristics of Colletotrichum from peach, apple, pecan, and other hosts. Plant Dis. 79:478-82.

5. Bushong, P. M., and Timmer, L. W. 2000 Evaluation of postinfection control of citrus scab and melanose with benomyl, fenbuconazole and azoxystrobin. Plant Dis. 84:12461249

6. Cline, W. O., and Bland, W. T. 1998. Evaluation of fungicides to control fruit rots of blueberry. Fungic. Nematic. Tests 53:63.

7. Denham, T. G. 1979. Citrus production and premature fruit drop disease in Belize. PANS 25:30-36

8. Fagan, H. J. 1984. Postbloom fruit drop of citrus in Belize: II. Disease control by aerial/ground spraying. Turrialba 34:179-186.

9. Freeman, S., Katan, T. and Shabi, E. 1998. Characterization of Colletotrichum species responsible for anthracnose diseases of various fruits. Plant Dis. 82:596-605.

10. Gadoury, D. M., and MacHardy, W. E. 1984 Integration of fungicide and insecticide applications in low inoculum orchards. Fungic. Nematic. Tests 39:10

11. Goes, A., and Kimati, H. 1998. Colletotrichum acutatum, agente causal da queda premature dos frutos citricos: resistente ou insensivel a benomyl? Summa Phytopathol. 24:246-53

12. Legard, D. E., and Chandler, C. K. 2000. Evaluation of fungicides to control Colletotrichum fruit rot of strawberry. Fungic. Nematic. Tests 55:123.

13. O'Leary, A. L., and Sutton, T. B. 1986. Effects of postinfection applications of the ergosterol biosynthesis inhibiting fungicides on lesion formation and pseudothecial development of Venturia inaequalis. Phytopathology 76:119-124.

14. Orozco Santos, M., and Gonzalez Garza, R. 1986. Caída de fruto pequeño y su control en naranja 'Valencia' en Veracruz. Agric. Tec. Mex. 12(2):259-269.

15. Peres, N. A. R., Souza, N. L., and Timmer, L. W. Postbloom fruit drop in Brazil and Florida:

Table 5. Effect of applications of citrus flower extracts (FE) or water followed by application of benomyl or water on the number of propagules/ $\mathrm{cm}^{2}$ of Colletotrichum acutatum produced on inoculated sweet orange leaves

\begin{tabular}{|c|c|c|c|c|c|c|c|c|c|c|c|}
\hline \multirow{2}{*}{\multicolumn{2}{|c|}{ Treatments $^{\mathbf{y}}$}} & \multicolumn{10}{|c|}{ Propagules $/ \mathrm{cm}^{2}$ of leaf ${ }^{\mathrm{x}}$} \\
\hline & & \multicolumn{2}{|c|}{ Experiment 1} & \multicolumn{2}{|c|}{ Experiment 2} & \multicolumn{2}{|c|}{ Experiment 3} & \multicolumn{2}{|c|}{ Experiment 4} & \multicolumn{2}{|c|}{ Mean } \\
\hline Day 1 & Day 3 & Pre & Post & Pre & Post & Pre & Post & Pre & Post & Pre & Post \\
\hline None & None & 8.7 & 1.5 & 14.2 & 12.1 & 9.4 & 8.1 & 5.8 & 3.8 & 9.5 & $6.4 \mathrm{~b}$ \\
\hline Water & None & 8.4 & 7.5 & 21.7 & 37.0 & 14.1 & 23.7 & 11.3 & 5.1 & 13.9 & $18.3 \mathrm{~b}$ \\
\hline FE & None & 21.4 & 52.9 & 23.2 & 82.8 & 15.1 & 52.1 & 2.8 & 11.7 & 15.6 & $49.9 \mathrm{a}^{\mathrm{z}}$ \\
\hline Water & Benomyl & 11.3 & 5.1 & 26.0 & 17.4 & 17.1 & 11.3 & 3.1 & 2.7 & 14.4 & $9.1 \mathrm{~b}$ \\
\hline FE & Benomyl & 2.4 & 7.5 & 19.5 & 22.4 & 15.4 & 12.2 & 14.5 & 13.0 & 13.0 & $11.4 \mathrm{~b}$ \\
\hline
\end{tabular}

$\mathrm{x}$ Pre $=$ sampled immediately before treatment on day 1; post $=$ sampled 3 days after treatment on day 3. Mean separation within columns by the WallerDuncan $k$-ratio $t$ test, $P \leq 0.05$.

${ }^{y}$ All plants sprayed with conidia 30 days prior to initiation of the experiment. Data are the means of 10 leaves collected from two different plants. Benomyl applied at $1.2 \mathrm{~g}$ a.i./liter.

${ }^{\mathrm{z}}$ The "Post" mean significantly different from the "Pre" mean according to the " $\mathrm{t}$ " test, $\mathrm{P} \leq 0.05$. All other across-column comparisons were not significant. 
occurrence and control by fungicides. Proc. Int. Soc. Citricult. In press.

16. Sonoda, R. M., and Pelosi, R. R. 1988. Outbreak of citrus postbloom fruit drop caused by Colletotrichum gloeosporioides from lesions on citrus blossoms in the Indian River of Florida. Proc. Fla. State Hortic. Soc. 101:36-38.

17. Stamps, R. H., Strandberg, J. O., and Norman, D. J. 1997. Incidence, severity and control of anthracnose in leatherleaf fern in Florida. Proc. Fla. State Hortic. Soc. 110:115-18.

18. Szkolnik, M. 1978. Techniques involved in greenhouse evaluation of deciduous tree fruit fungicides. Annu. Rev. Phytopathol. 16:103129.

19. Szkolnik, M. 1979. Postinfection evaluation of fungicides in the greenhouse for apple scab control. Fungic. Nematic. Tests 35:21.

20. Timmer, L. W., Agostini, J. P., Zitko, S. E., and Zulfiqar, M. 1994. Postbloom fruit drop of citrus, an increasingly prevalent disease of citrus in the Americas. Plant Dis. 78:329-334.

21. Timmer, L. W., and Brown, G. E. 2000. Biology and control of anthracnose diseases of citrus. Pages 300-316 in: Host Specificity, $\mathrm{Pa}-$ thology, and Host-Pathogen Interactions of Colletotrichum. D. Prusky, S. Freeman, and M. B. Dickman, eds. American Phytopathological Society Press, Inc., St. Paul, MN

22. Timmer, L. W., Brown, G. E., and Zitko, S. E. 1998. The role of Colletotrichum spp. in postharvest anthracnose of citrus and survival of C. acutatum of fruit. Plant Dis. 82:415418.

23. Timmer, L. W., and Zitko, S. E. 1992. Timing of fungicide applications for control of postbloom fruit drop of citrus in Florida. Plant Dis. 76:820-823.
24. Timmer, L. W., and Zitko, S. E. 1993. Techniques for greenhouse evaluation of fungicides for control of citrus scab. Pages 125-129 in: Proc. IV Congr. Int. Soc. Citrus Nurserymen. E. Rabe, ed. Sun City, South Africa.

25. Timmer, L. W., and Zitko, S. E. 1996. Evaluation of a model for prediction of postbloom fruit drop of citrus. Plant Dis. 80:38-383.

26. Whiteside, J. O. 1973. The possibilities of using ground sprays to control citrus greasy spot. Proc. Fla. State Hortic. Soc. 96:19-23.

27. Whiteside, J. O. 1977. Sites of action of fungicides in the control of citrus melanose. Phytopathology 67:1067-1072.

28. Zulfiqar, M., Brlansky, R. H. , and Timmer, L. W. 1996. Infection of flower and vegetative tissues of citrus by Colletotrichum acutatum and C. gloeosporioides. Mycologia 88:121128. 